\title{
Safety assessment of cosmetic products, with emphasis on the ocular area: regulatory aspects and validation processes
}

\author{
Maythê de Lima Cancian', Mauricio Saadi Leonardi ${ }^{3}$, Mariane Martins Mosca ${ }^{4}$, \\ Lucas Offenbecker Guerra ${ }^{5}$, Simone Fanan Hengeltraub ${ }^{5}$, Gislaine Ricci Leonardi ${ }^{1,2, *}$
}

\begin{abstract}
${ }^{1}$ Institute of Environmental Chemistry and Pharmaceutical Sciences, Federal University of São Paulo, Diadema, São Paulo, Brazil, ${ }^{2}$ Medicine Department, Federal University of São Paulo, São Paulo, SP, Brazil, ${ }^{3}$ Ophthalmologist, ${ }^{4}$ Grupo Investiga, Campinas, São Paulo, Brazil, ${ }^{5}$ TRIDSKIN Laboratórios Ltda., Grupo Investiga, Campinas, São Paulo, Brazil
\end{abstract}

\begin{abstract}
Before marketing a cosmetic product, a series of biological assays, such as ocular irritation tests, must be conducted in order to prove that the product is safe. However, a few scientific articles mention the discussion and evolution of cosmetic products testing performed in the eyes area. The aim of this study was to review the available literature on the evolution of tests carried out with cosmetics, in the ocular area, as well as to describe the methodologies that have been used and that are currently accepted. In Brazil, tests performed on animals are still allowed. However, the international laws strongly recommend the use of alternative methods for evaluating the risk of cosmetic ingredients and products. Regulatory requirements involving the registration of these products also request safety support of them in human beings. To perform ocular tests in human beings, it is necessary to involve an ophthalmologist for conducting clinical protocols. These protocols signed by the expert physician are sent to the National Health Surveillance Agency in order to endorse the product manufacturer concerning its safety. The safety support of a cosmetic product is very important, taking into account that the consumer has free access to these products of widespread use in today's society.
\end{abstract}

Uniterms: Eyes/cosmetics use. Cosmetics/safety assessment. Ocular irritation/tests. Ocular area/safety use of cosmetics

Com o objetivo de comprovar que um produto cosmético é seguro, antes que este seja colocado no mercado, este deve passar por uma série de ensaios biológicos, que avaliem sua segurança, como, por exemplo, os testes de irritação ocular. Porém, poucos artigos científicos trazem a discussão e a evolução sobre os testes de produtos cosméticos realizados na área dos olhos. O objetivo desse trabalho foi realizar uma revisão bibliográfica sobre a evolução dos testes realizados com cosméticos, na região ocular, bem como descrever as metodologias que já foram utilizadas e as que são aceitas atualmente. No Brasil, são ainda permitidos testes em animais, entretanto, as legislações internacionais indicam fortemente a utilização de métodos alternativos para avaliação de risco de ingredientes e produtos cosméticos. As exigências regulatórias que envolvem o registro desses produtos solicitam também a comprovação de segurança destes produtos em serem humanos. Para a realização dos testes oculares em humanos, é necessário o envolvimento de um oftalmologista na condução de protocolos clínicos. Esses protocolos assinados pelo médico especialista são enviados à Agencia Nacional de Vigilância Sanitária, a fim de respaldar o fabricante do produto sobre a segurança do mesmo. A comprovação da segurança de um produto cosmético é bastante importante, considerando-se o livre acesso aos consumidores e o amplo uso desses produtos na sociedade atual.

Unitermos: Olhos/uso de cosméticos. Cosméticos/segurança. Irritação ocular/testes. Região ocular/uso seguro de cosméticos

\footnotetext{
*Correspondence: G. R. Leonardi. Instituto de Química Ambiental e Ciências Farmacêuticas, Universidade Federal de São Paulo. Rua São Nicolau, 210, 09913-030 - Diadema - SP. E-mail: grleonardi@hotmail.com
} 


\section{INTRODUCTION}

The Brazilian health legislation comprises several regulatory rules (Laws, Decrees, Resolutions, Ordinances, etc.). The role of the National Health Surveillance Agency is to regulate, control and supervise the processes, products, supplies and services that can potentially be harmful to the population's health. In Brazil, these activities received a great stimulus with the creation of the National Health Surveillance Agency - ANVISA (Lucchese, 2001).

In order to ensure the consumer is purchasing safe and quality products, ANVISA is responsible for authorizing the marketing of toiletries, cosmetic and fragrance products, by granting the manufacturer the product registration or notification. ANVISA also supervises and sets standards for the manufacturing companies, by checking the production process, the techniques and methods used until the final consumption. Thus, both the production and the marketing process of cosmetic products in Brazil are regulated by ANVISA and, therefore, subjected to its supervision.

According to the Guide for the Safety Evaluation of Cosmetic Products of ANVISA, cosmetics, fragrances and toiletries are formulations constituted by natural or synthetic substances for external use on several parts of the human body: skin, hair, nails, lips, external genital organs, teeth and mucous membranes of the oral cavity, aiming exclusively to clean, scent, change the aspect and/ or correct body odors and/or protect or keep them in good condition (ANVISA, 2003).

Cosmetics, as well as toiletries and fragrance products are classified according to the degree of risk they offer, in which grade 1 represents the products with minimal risk and grade 2 products with potential risk (RDC 211, 2005). The criteria for this classification were defined by ANVISA according to the intended product use, body areas covered, use directions and any special care to be observed during use (Leonardi, 2008).

For marketing products rated as Risk Level 1, a notification must be sent 30 days prior to their marketing. For submitting the notification, it is not necessary to submit studies to prove its safety and efficacy. However, the National Health Surveillance Agency may require the manufacturer to present at any time, the safety tests performed. Thus, it is important for the manufacturer to properly evaluate the safety of the product and maintain all study records.

Products rated as Risk Level 2 are those with specific recommendations, which characteristics require safety and/or efficacy support, as well as information and special care concerning the use directions and restrictions, in that it is mandatory to present this information when requesting the product registration (RDC 343, 2005).

The safety evaluation of cosmetic products before marketing is extremely important for preserving consumer's health. The first exposure to a new cosmetic product must occur in a controlled and monitored way, in clinical studies monitored by expert physicians, and not in a large scale, in the consumer market. It is a way to prevent the occurrence of unexpected reactions directly to the consumers, preserving the health and wellbeing of the population.

Despite the existence of different processes for products registration and notification, the importance must be directed to the conduction of an appropriate safety evaluation of the products. Resolution No. 79 of August $28^{\text {th }}, 2000$ updates the list of allowed, allowed with use restricted to certain conditions or prohibited substances in cosmetic products, and updates the standards and procedures contained in Resolution 71/96 concerning the registration of toiletries, cosmetic and fragrance products and others included in this context. Products categories not existing in Resolution 71/96 were also created. A cream for cellulite or stretch marks, for example, that had no specific category before, with the publication of Resolution 79, enters the category "cellulite/stretch marks cream" and is rated as a product of risk level 2 . The same occurs with body products containing SPF that are now rated as products of risk level 2 (RDC 79, 2000).

As a consequence, besides using safe raw materials covered by the conditions outlined in the lists of substances made available by the Regulatory Agency, the industry should have the results proving the safety of every marketed cosmetic product.

When submitting their products for clinical trials, the company must ensure they do not offer foreseeable risks for the subjects and that the raw materials used are consecrated and do not represent health risk. Furthermore, the company should confirm that ingredients unauthorized by the Regulatory Agency are not used and, in the case of regulated ingredients, that they are not used at concentrations above those allowed. This information must be explained and evidenced through a Responsibility Statement issued by the sponsor.

Currently, a wide range of tests allows evaluating a cosmetic product regarding its safety in many different aspects. It is possible to evaluate the finished product or its raw materials.

These studies comprise non-clinical assays - in which raw materials or finished products are evaluated in animals or through in vitro methods - and clinical trials in 
which the finished product is tested on human subjects.

In vitro non-clinical assays are important today for replacing the tests performed in animals, with some alternative methods already internationally validated. Initially developed to properly meet the needs of the pharmacology studies, alternative methods were also used to evaluate the toxicological effects (ANVISA, 2012). They are of a great importance to evaluate new raw materials.

After running pre-clinical tests, the product safety when in human use should be evidenced by clinical studies results (ANVISA, 2012).

The clinical trials aim to confirm the safety of the finished product, taking into account possible interactions between the ingredients, which are required for products registration (ANVISA, 2003).

The clinical and non-clinical studies may prove the safety of components or finished products, by evaluating the potential for skin irritation, photoallergy and phototoxicity, ocular irritation, acnegenicity, comedogenicity, sensitization, among others.

The ocular irritation studies are not required for registration, unless the manufacturer wishes to explore as product claims expressions like "Ophthalmologically Tested" or "Tear-free", for example. However, it is important to highlight that if any consumer reports any unwanted effect in the eyes, the manufacturer may be required to present tests confirming the product safety in this area.

Therefore, although mandatory only in cases in which special claims are used on the product labels, tests in the ocular area are extremely important, since toxic profile products may cause injury when in contact with the eyes (Azevedo, 2003), as occurred in the 30s in the United States with Lash Lure ${ }^{\circledR}$ cosmetics, which made at least 12 individuals go blind. These cosmetics were used in beauty salons as permanent colorant for eyelashes and eyebrows. Its composition comprised amine paraphenylene, a substance with high dermal-sensitizing potential, causing, weeks after use, severe corneal damages to its consumers. (Wilhelmus, 2001; Nóbrega et al., 2008).

\section{Non-clinical studies in animals}

The non-clinical test for evaluating the ocular irritation potential of a compound was first described in 1944 by John H. Draize and his collaborators (Alves, 2003). This test was performed on at least six albino rabbits of the New Zealand breed, where about $0.1 \mathrm{~mL}$ of the substance at different concentrations was applied to one eye of the rabbit, while the other one served as control.
Then, the eyelids were held together for a few seconds. There was no eyes washing, allowing only the tearing to do the removal. The eyes were examined after 1, 24, 48 and 72 hours of application. If the reactions were positive, the evaluations continued for up to seven days. Damages to the cornea (opacity), iris (hyperemia, hemorrhage and edema) and conjunctiva (hyperemia, chemosis and secretion) were evaluated in the eyes of the rabbits and, for each lesion, a score at different degrees was assigned, according to the intensity of the reaction observed (Draize, Woodard, Calvery, 1944; McNamee, 2011).

However, the Draize test came under constant criticism by both those who defend the animal welfare and the scientific community, which questioned the variability of the results obtained, the subjectivity of the ocular damages and the overestimation of the effects in humans by using high doses of the product. These criticisms led to the search for alternative procedures that aimed to reduce the number of animals used or to develop studies for replacing testing in animals (Costa, 2006).

\section{In vitro non-clinical studies}

During the last years many changes have occurred not only in the cosmetic legislation but also in the chemical legislation of the European Union (REACH, "Registration, Evaluation, Authorization and Restriction of Chemicals"). The concept of the 3Rs appeared with the publication of "The Principles of Humane Experimental Technique" in 1959 by William Russell \& Rex Burch, which refers to the refinement, reduction and substitution of the tests performed in animals (Cazarin, Corrêa, Zambrone, 2004; Zuang, 2011). In 1978, David Smyth presented the definition of the 3 Rs concerning the alternative experimentation, which includes all procedures that can completely replace the use of animals in experiments, that reduce the number of animals required, or that reduce the pain and suffering of these animals. However, it was only during the 70 s and 80 s that the international laws were changed and redefined based on the 3Rs concept. In 1993, one year after the creation of the European Centre for the Validation of Alternative Methods (ECVAM), with the 1st World Congress on the Use of Animals and Alternative Methods in Science, the worldwide movement based on the 3R's really started.

During the past 25 years the most important step taken was the establishment of ECVAM and then the creation of the American equivalent ICCVAM in 1997. Soon after, in 2003, the $7^{\text {th }}$ Amendment of the European Cosmetics Directive was established. This amendment establishes a prohibition of animal testing in finished 
cosmetic products and cosmetic ingredients ("Testing Ban"). It also establishes a prohibition for marketing finished cosmetic products and ingredients included in cosmetic products, which have been tested on animals in the European community ("Marketing Ban"). The "Testing Ban" on finished cosmetic products has already been applied since September 11 $1^{\text {th }}, 2004$ in the European Union countries. The "Testing Ban" on the ingredients or combination of ingredients has been progressively applied, concomitantly with the validation and adoption of alternative methods, but with a deadline of 6 years after 2003 , i.e. March $11^{\text {th }}, 2009$. The "Marketing Ban" will be progressively applied when the alternative methods are viable and adopted by the European legislation with the right consideration by the process of the OECD validation. This "Marketing Ban" was introduced on March $11^{\text {th }}$, 2009 for all the human adverse effects studies, except for toxicokinetics, repeated dose and reproductive toxicity studies. For these specific studies a deadline of 10 years was defined after the entry of the $7^{\text {th }}$ Amendment to start the "Marketing Ban", i.e. March 11 ${ }^{\text {th }}, 2013$, regardless the viability or not of the alternative methods.

All these changes indicate that the responsibility for the safety of cosmetics - and their ingredients - brought to the European market is placed on the manufacturer, first European importer or the trader of these products. This means that since March 2013, the cosmetics safety evaluation will only be possible in Europe by using validated in vitro models. That is, only alternative methods fully replacing the assays performed on animals have been accepted, eliminating all the tests performed on animals for the non-clinical evaluation of cosmetic ingredients and products. Other methods that were claimed to be alternative and that refined or reduced the use of animals are not accepted since 2013.

A retrospective validation study on four organotypic assays, i.e. the Bovine Corneal Opacity \& Permeability test (BCOP), the Isolated Chicken Eye test (ICE), the Isolated Rabbit Eye test (IRE) and the Hen's Egg Test on the Chorioallantoic Membrane (HET-CAM), was conducted between 2003 and 2006 by ICCVAMNICEATM, with ECVAM collaboration, to assess the ability of these assays for detecting severe eye irritants and ocular corrosives. After peer review, two assays, the BCOP and ICE tests, were endorsed as scientifically valid to identify ocular corrosives and severe irritants in the US and EU (ICCVAM, 2006a). Test guidelines for these two test methods were adopted by OECD Council on $7^{\text {th }}$ September, 2009 as OECD Test Guidelines (TG) 437.

In Brazil, despite the constant effort for reducing and replacing the use of animals for safety studies, tests using animals are still accepted by ANVISA with no expected prohibition (ANVISA, 2003). The main ophthalmological safety tests recommended by ANVISA through the Safety Guide (2003) are:

- $\quad$ HET-CAM ("Hen's Egg Test-Chorioallantoic Membrane"); BCOP (“Bovine Cornea Opacity Permeability”).

\section{HET-CAM Alternative method}

The purpose of the assay is to assess the ocular irritation potential of a product (soluble, emulsion, gel and oil products) in the Chorioallantoic Membrane of embryonated chicken egg, on the tenth day of incubation. The assay is based on the observation of irritant effects (hyperemia, hemorrhage and coagulation) for 5 minutes after pure or diluted product application, in the chorioallantoic membrane. The method is practical, with high sensitivity and low cost, however, it is not effective with very viscous and adherent products, because it causes washing and removal procedures to be hard after 20 seconds of application in the membrane (Liebsch, Spielmann, 2002; McNamee, 2011). This test has not been validated by the international validation centers and is being reviewed by ECVAM and ICCVAM to be validated and accepted by the regulatory agencies. However, it is well accepted for evaluating ocular irritation of chemicals substances by REACH.

\section{BCOP Alternative method}

The Bovine Corneal Opacity and Permeability (BCOP) test method was evaluated by the Interagency Coordinating Committee on the Validation of Alternative Methods (ICCVAM), in conjunction with the European Centre for the Validation of Alternative Methods (ECVAM) and the Japanese Center for the Validation of Alternative Methods (JaCVAM), in 2006 and 2010 (1) (2). In the first evaluation, the BCOP test method was evaluated concerning its usefulness to identify chemicals (substances and mixtures) inducing serious eye damage (1). In the second evaluation, the BCOP test method was evaluated concerning its usefulness to identify chemicals (substances and mixtures) not classified for eye irritation or serious eye damage.

The aim of the assay is to quantitatively evaluate the irritant potential of a chemical substance after the application in the isolated bovine cornea. The assay is based on the measurement of the opacity and permeability of the bovine cornea after contact with the test product.

- Measurement of the opacity of the cornea - per- 
formed by using an opacimeter, device that determines the difference of transmission of the luminous flow in the cornea to be evaluated, setting a numerical value of opacity.

- $\quad$ Measurement of the permeability of the cornea performed according to the contact time, by adding fluorescein and measuring the optical density at $490 \mathrm{~nm}$. A scale is then obtained by considering the observed phenomena.

The OECD TG437 (adopted in 2009 and updated in 2013) includes the recommended use and limitations of the BCOP test method based on its evaluations. The identified limitations for the BCOP test method are based on the high false positive rates for alcohols and ketones and the high false negative rates for solids observed in the validation database.

The test is a good alternative to the Draize method, since it is fast and has good prediction of the ocular irritation degree of a wide variety of substances (Price, Andrews, 1985; Gordon, Kelly, 1989; Van Goethem, 2011), and it has already been validated by ECVAM and ICCVAM, reviewed by ESAC with the OECD number TG437. This test is known as an organotypic study - study that uses isolated animal organs.

The ability of the BCOP test method to identify all categories of ocular irritation potential, as defined by the EPA (Environmental Protection Agency), EU (European Union), and GHS (Globally Harmonized System) classification systems (EPA 2003a) (EU 2008) (UN 2009), was evaluated by ICCVAM (2010a). Based on the current BCOP validation database ( $\mathrm{n}=211$ substances), which was updated since the ICCVAM evaluation of the BCOP test method for identifying ocular corrosives and severe irritants (ICCVAM 2006b), the overall correct classification ranged from $49 \%(91 / 187)$ to $55 \%$ $(102 / 187)$ when evaluating the entire database, depending on the hazard classification system used. Based on these performance statistics, the BCOP test method is not considered to be valid as a complete replacement for the in vivo rabbit eye test for identifying all categories of ocular irritation (i.e. EPA Category II, III, IV; GHS Category 2A, 2B, Not Classified; EU Category 2, Not Classified). Test substances inducing serious eye damage are classified as UN GHS Category 1. Chemicals not classified for eye irritation or serious eye damage are defined as those that do not meet the requirements for classification as UN GHS Category 1 or 2 (2A or 2B), i.e. they are referred to as UN GHS No Category. The BCOP test method was chosen to be used within a testing strategy such as the Top-Down/ Bottom-Up approach suggested by Scott et al. (2010).

\section{Top-down/bottom-up strategy}

Scott et al. (2010) published the outcome of an ECVAM expert meeting, with the aim of identifying testing strategies for eye irritation. A hazard identification testing scheme was proposed using a bottom-up (starting with test methods able to accurately identify nonirritants) or top-down (starting with test methods able to accurately identify severe irritants) progression of in vitro tests. As such, the approach intends to identify non-irritants and severe irritants, leaving all others to the (mild/moderate) irritant categories. Once the identification of non-irritancy to the eye through an in vitro methodology is today not yet possible, the practical value of the proposal is limited.

\section{Cytotoxicity tests}

Furthermore, the cytotoxicity tests by the assay methods of mitochondrial metabolic activity (MTT), neutral red (NRU) and Red Blood Cell System (RBC) are also accepted by ANVISA and can be an alternative to the Draize test (Bednarczuk et al., 2010); although these tests are not validated by ECVAM for ocular irritation assessment.

The cytotoxicity assay by the RBC method studies the effects of products and their ingredients isolated on the plasma membrane of red blood cells, analyzing the phenomena of hemolysis and denaturation of hemoglobin. The relation between the hemolysis and the hemoglobin oxidation provides a parameter to characterize the in vitro effects of these substances (Wolfgan, Pfnnenbecker, Hoppe, 1987). This method, however, was not approved in the validation process of ECVAM and ICCVAM.

The MTT measures the mitochondrial activity of the viable cells in metabolizing the tetrazolium salts, by using cell cultures with MTT vital colorant. The evaluation final parameter is to establish the IC50 (the concentration of test substance that inhibits $50 \%$ of cell growth). It is not applicable to products that are not soluble in water or ethanol and or DMSO (Abreu, 2008). This end-point is applied for evaluating skin irritation in 3D models of epidermis that is equivalent to the one that has been validated and has the OECD number 439. It is necessary to check the method for possible direct MTT reduction with test substances. This verification should be done before starting the experiments.

Finally, as in the cytotoxicity method with MTT, the cytotoxicity method with neutral red (NRU) uses cell culture with a vital colorant, the NR, or the neutral red colorant. The method measures the retention activity of 
the colorant by the lysosomes of the viable cells and is described at ISO 10.993-5. The evaluation final parameter is also the establishment of IC50. This method cannot be used for studying substances that have fixing properties (Tani et al., 1999). This method has been validated to reduce the number of animals used for evaluating the Acute Oral Toxicity of chemical substances, and it is described in OECD TG129.

Following the study of irritation potential of raw materials in non-clinical assays, the finished product goes to the second phase of safety tests, to be performed in human subjects. The clinical studies are required because many times the response to certain substances in humans can be different when compared with the responses observed in animals - situation called idiosyncrasy. These tests are usually outsourced by the cosmetic industries. In Brazil, there are several research institutes that provide such services, which must be qualified by ANVISA or INMETRO (Raymundo, Goldim, 2002).

\section{Processes of in vitro method validation}

Validated alternative methods are those which relevance (scientific basis and predictive ability of the test system) and reproducibility (reproducibility of test results obtained within a laboratory and among laboratories) have been established for a particular purpose. An alternative method for the replacement of a test conducted on animals is a combination of a test system, and a prediction model. The test system generates a number of physico-chemical data or in vitro data for the chemical substance of interest. The prediction model or data interpretation procedure is an unambiguous algorithm to convert these data to predict in vivo toxicology results, called in animals or humans.

The criteria and procedures for validating methods have been developed and implemented in Europe by the ECVAM - European Centre for the Validation of Alternative Methods and its independent Committee ESAC - European Scientific Advisory Committee, in the United States by the ICCVAM - Interagency Coordinating Committee on the Validation of Alternative Methods, in Japan by the JaCVAM - Japanese Centre for the Validation of Alternative Methods and internationally by the OECD - Organization for Economic Co-Operation and Development.

The main objective of this validation body is to promote the scientific and regulatory acceptance of alternative methods through research, development and validation of new tests, aiming to contribute for the principle of the 3Rs (Reduction, Refinement and Replacement of animal tests).
Before an alternative method is officially accepted by the regulatory agencies, it is essential that the validity of the new methods be demonstrated in an independent validation and scientifically accurate program. However, until 1990 there was no scientific approach on the subject or a guide of the regulatory agencies for the experimental validation of in vitro toxicity tests. During the second validation workshop, held in Amden in 1994 and chaired by ECVAM, essential elements for the validation process were defined. In 1995/96 the validation procedure of ECVAM was officially accepted by the member-countries of the European Union and by the international official agencies such as the American agencies and the OECD. The concept of validation was immediately installed and, in 1998, the NRU 3 T3 phototoxicity in vitro test was the first experiment successfully validated using this concept. Today there are several other valid and in process of validation methods and a few that have been validated and approved by international regulatory agencies (Eskes et al., 2005).

The ECVAM is the international reference center for the development and validation of alternative methods directed for replacement, reduction and refinement of animal use in biomedical science, with emphasis on the toxicological evaluation. This center was founded by the European Commission in 1992 to achieve the objectives of Directive 86/609/EC about the protection of animals used for experimental and other scientific proposals (Eskes et al., 2005).

According to ECVAM, validation is the process by which trust and relevance of the procedure are established for a particular purpose (Balls et al., 2006). And validated methods are those that comply with the validation process adopted in the European Union by ECVAM and its Committee of Independent Consultants ESAC. During the pre-validation process, the method must first become valid. Since the alternative method went through the process of pre-validation and validation, it will be analyzed by the SCCP (Scientific Committee on Consumer Products). After approval by the SCCP, it will be submitted for approval by the regulatory agencies and written OECD guideline. That being said, it is clear that the process of validation of any alternative method for safety evaluation of chemical substances and finished products in Brazil is a factor of scientific, technological and industrial development and competitiveness for the cosmetic, sanitizing, pesticides and pharmaceutical industry.

\section{Clinical studies}

Since the cosmetic products are produced with raw 
materials known to be safe, as per the lists of ingredients made available by the Regulatory Agency and found in the literature, and that new raw materials are incorporated in these products only after they have been extensively studied through pre-clinical tests, the clinical studies aim to prove the safety of these products in humans. These studies allow knowing the action of the product, directly into the target public, on the mucosa or on the skin from different body areas.

Tests conducted with humans are governed by very strict laws in order to protect and safeguard people. These laws vary from country to country. In Brazil, these studies are allowed, provided that they comply with the precepts of the Helsinki Declaration and the CNS 196/96 (RDC 196, 1987). In addition, the product evaluation in humans must follow the Good Clinical Practices (GCP), for the welfare of the study subject and evaluation of the benefitrisk relation associated with the study.

There are different studies for evaluating the ocular irritation potential of cosmetic products in humans. Some studies are performed under controlled and maximized conditions (Ocular instillation study), while others evaluate the product under real use conditions (Ophthalmological Acceptance studies).

Before testing a cosmetic product in the ocular area which is a mucous tissue area, highly sensitive and of high permeation - it is important to know and prove its safety through compatibility clinical studies. In compatibility studies, the products are tested under occlusive or semiocclusive maximized condition, by using adhesives (patch tests) attached to the back or forearm of the study subject, with the objective of proving the absence of irritant or allergenic potential.

Next, the Ocular Irritation studies are suggested. The most appropriate type of study, Ocular instillation or Ophthalmological Acceptance, is determined according to the product category. The Ocular Instillation test is recommended for rinse-off products for children, such as shampoos, conditioners and liquid soaps/body washes. These are products that, during use, may have direct contact with the children's ocular mucosa. It is suitable for children's products, because they are products that have lighter formulations with lower concentrations of surfactants. Through this test, it is possible to explore claims such as "Tear-free" and "No Tears". The Ophthalmological Acceptance studies are recommended for products to be used on the face or on the periocular area, such as makeup (eyeliner, eye pencil, mascara) and facial or eye-area creams. In this case, the most suitable exposure is under real use conditions for evaluating safety.
The Ocular irritation test by instillation consists in applying the product - diluted in physiological solution at predetermined concentrations -directly to the subjects' eyes. In these studies, the subjects are initially assessed by an Ophthalmologist using a slit lamp, for checking their eligibility. This selection is made by following specific exclusion criteria, such as: conjunctival corneal conditions and periocular area conditions, use of contact lenses, pregnancy/lactation, and other diseases or medications that may directly interfere in the study or endanger the subject's health.

The diluted product is then instilled into the conjunctival sac of one eye of the subjects while drops of physiological solution are instilled in the other eye, which will serve as a control. After instillation, subjects are assessed again by the ophthalmologist for assessing and rating ocular signs and symptoms, such as hyperemia and burning. New visits to the institute are held in order to assess possible adverse events that may arise later. The scores given by the ophthalmologist are used to calculate the degree of ocular irritation of the product.

Through this study the ophthalmologist is able to run a qualitative assessment of the increased tears caused by the product, allowing the evaluation and support of claims such as "Tear-free" and "No Tears".

On the other hand, in Ocular Acceptance studies, the product is tested under real use conditions. That is, the study subject uses the product at home, according to the use directions specified by the manufacturer (ANVISA, 2003).

In the acceptance studies, subjects are initially assessed by a physician. If approved, they are allowed to take the test product to be used at home - according to the use directions recommended by the manufacturer - and are examined again at the end of the study, usually after 3 or 4 weeks of product use.

It is important to have such studies supervised by an ophthalmologist, since many ocular parameters are assessed. The external area of the eye is formed by the conjunctival membrane and by the cornea. The cornea is the most important external tissue formed by lamellar fibers parallel distributed, which gives it optical transparency. This is a tissue with several nerve endings, therefore extremely sensitive to pain. Its most external layer, the epithelium, acts as a barrier to microorganisms' entry. Therefore, any epithelial lesion of the cornea predisposes to an infection, which may cause corneal ulcer and a permanent lesion. Many studies consider the use of fluorescein - a commercial eye drop widely used in ophthalmological clinical centers - because its coloring action allows evaluating corneal lesions, if any. 
These studies are important because they allow evaluating the product under real use conditions, in which specific characteristics of the product or of its use directions can be identified and then taken into account for developing the content of the product label. Therefore, they represent a more appropriate evaluation of products applied close to the eyes, because they allow identifying responses under predictable use conditions and also under inappropriate/incorrect use conditions. This allows the manufacturer to have more information and thus more technical background to define the use directions of the product, as well as the use precautions.

The number of subjects required for a study varies according to specific protocols of the study centers and according to the recommendation of the Guide for the Safety Evaluation of Cosmetic Products of ANVISA. The Acceptance studies, for example, must be completed with a minimum number of 30 responses, as mentioned in the Safety Guide of ANVISA. The Irritation studies by instillation - as they occur under maximized and very controlled conditions may be completed with a smaller number of responses.

\section{CONCLUDING REMARKS}

The safety support of a cosmetic product is very important, taking into account that the consumer has free access to these products of widespread use in today's society. Every year, new products for eyes are launched, such as makeup items and face creams, and therefore the number of consumers has increased considerably.

Proving that products applied too close to the eyes are safe - by evaluating their ocular irritation potential - is very important because direct contact with the eyes may occur in several situations: incorrect application of product, sweating or even skin scratching.

The concern with rigorous and effective ophthalmological studies is essential so that ophthalmologically safe products are launched on the market.

\section{REFERENCES}

ABREU, C.L.C. Avaliação da citotoxicidade induzida por produtos cosméticos pelo método de quantificação de proteinas totais em células 3T3. Rio de Janeiro, 2008. 104 p. [Dissertation of Master degree. Fundação Oswaldo Cruz. Instituto Nacional de Controle de Qualidade em Saúde].
ALVES, E.N. Red Blood Cell (RBC) - Teste de hemólise: uma alternativa ao teste de draize-irritação ocular na avaliação do poder tóxico de produtos cosméticos no controle de qualidade. Rio de Janeiro, 2003. 89 p. [Dissertation of Master degree. Instituto Nacional de Controle de Qualidade em Saúde. Fundação Oswaldo Cruz].

AGENCIA NACIONAL DE SEGURANÇA SANITÁRIA. ANVISA. Guia para avaliação de segurança de produtos cosméticos. Brasília, 2003. Available at: <http://www. anvisa.gov.br/cosmeticos/guia/guia_cosmeticos_final_2. pdf $>$. Accessed on: 06 Nov. 2014.

AZEVEDO, J.C. Avaliação de metodologia alternativa in vitro ao teste de irritação ocular de Draize. São Paulo, 2003. 139 p. [Dissertation of Master degree. Faculty of Pharmaceutical Sciences, University of São Paulo].

BALLS, M.; AMCOFF, P.; BREMER, S.; CASATI, S.; COECKE, S.; CLOTHIER, R.; COMBES, R.; CORVI, R.; CURREN, R.; ESKES, C.; FENTEM, J.; GRIBALDO, L.; MARLIES, H.; HARTUNG, T.; HOFFMANN, S.; SCHECHTMAN, L.; SCOTT, L.; SPIELMANN, H.; STOKES, W.; TICE, R.; WAGNER, D.; ZUANG, V. The principles of weight of evidence validation of test methods and testing strategies. Altern. Lab. Anim., v.34, n.6, p.603620, 2006.

BEDNARCZUK, V.O.; VERDAM, M.C.S.; MIGUEL, M.D.; MIGUEL, O.G. Testes in vitro e in vivo utilizados na triagem toxicológica de produtos naturais. Visão Acadêmica, v.11, n.2, p.43-50, 2010.

CAZARIN, K.C.C.; CORRÊA, C.L.; ZAMBRONE, F.A.D. Redução, refinamento e substituição do uso de animais em estudos toxicológicos: uma abordagem atual. Rev. Bras. Ciênc. Farm., v.40, n.3, p.289-299, 2004.

COSTA, R.N. Estudo da aplicabilidade do ensaio de quantificação de proteínas totais em células SIRC na avaliação do potencial de irritação ocular de xampus e tensoativos. Rio de Janeiro, 2006. 60 p. [Dissertation of Master degree. Escola Nacional de Saúde Pública Sérgio Arouca, Fundação Oswaldo Cruz].

CRUZ, A.S. Teste de citotoxicidade in vitro como alternativa ao teste in vivo de Draize na avaliação de produtos cosméticos. São Paulo, 2003. 119 p. [Thesis of PhD degree. Faculty of Pharmaceutical Sciences, University of São Paulo]. 
DRAIZE, J.H.; WOODARD, G.; CALVERY, H.O. Methods for the study of irritation and toxicity of substances applied topically to the skin and mucous membranes. J. Pharmacol. Exp. Ther., v.82, p.377-390, 1944.

ENVIRONMENTAL PROTECTION AGENCY. EPA. Label review manual. 3ed. EPA 735-B-003-001. Washington: Environmental Protection Agency, 2003a.

ESKES, C.; BESSOU, S.; BRUNER, L.; CURREN, R.; HARBELL, J.; JONES, P.; KREILING, R.; LIEBSCH, M.; MCNAMEE, P.; PAPE, W.; PRINSEN, M.; SEIDLE, T.; VANPARYS, P.; WORTH, A.; ZUANG, V. In alternative (non-animal) methods for cosmetics testing: current status and future prospects. ATLA, v.33, suppl.1, p.47-81, 2005.

EUROPEAN COMMISSION. Legislação Cosmética $1223 / 2009$. Regulation (EC) $N^{\circ} 1223 / 2009$ of the European Parliament and of the Council of 30 November 2009 on cosmetic products. Off. J. Eur. Union, L342, p.59-209.

EUROPEAN UNION. EU. Regulation (EC) No 1272/2008 of the European Parliament and of the Council of 16 December 2008 on classification, labelling and packaging of substances and mixtures, amending and repealing Directives 67/548/EEC and 1999/45/EC, and amending Regulation (EC) No 1907/2006. Off. J. Eur. Union, L353, p.1-1355, 2008.

GORDON, V.C.; KELLY, C.P. An in vitro method for determining ocular irritation. Cosmet. Toiletr., v.69, n.10, p.69-74, 1989.

JACKSON, E.M. Eye irritation in cosmetic safety. A primer of cosmetics scientists. WHITTAM, J.H. (Ed.) Cosmetics science and technology series. New York: Marcel Dekker, 1987. v.5, n.53-62.

ICCVAM. Test method evaluation report: current validation status of in vitro test methods proposed for identifying eye injury hazard potential of chemicals and products. NIH Publication No. 10-7553. Research triangle park. NC: National Institute of Environmental Health Sciences. 2010a. Available at: <http://iccvam.niehs.nih.gov/methods/ocutox/ MildMod-TMER.htm>. Accessed on: May 2013.
ICCVAM. Guidelines for histopathological evaluation of bovine corneas as an endpoint of the bovine corneal opacity and permeability (BCOP) Assay (provided by the Institute for In Vitro Sciences, Gaithersburg, MD). In: ICCVAM Test method evaluation report: current validation status of a proposed in vitro testing strategy for U.S. environmental protection agency ocular hazard classification and labeling of antimicrobial cleaning products. NIH Publication No. 10-7513. Research Triangle Park, NC: National Institute of Environmental Health Sciences. 2010b. Available at (see Annex G): <http://iccvam.niehs.nih.gov/methods/ocutox/ AMCPsubmit.htm>. Accessed on: May 2013.

LEONARDI, G.R. Cosmetologia aplicada. 2.ed. São Paulo: Editora Santa Isabel, 2008. p.6-8.

LIEBSCH, M.; SPIELMANN, H. Currently available in vitro methods used in the regulatory toxicology. Toxicol. Lett., v.127, n.1-3, p.127-34, 2002.

LUCCHESE, G. Globalização e regulação sanitária: os rumos da vigilância sanitária no Brasil. Rio de Janeiro, 2001. 245 p. [Thesis of PhD. Fundação Osvaldo Cruz].

McNAMEE, P. In vivo and in vitro evaluation of eye irritation, including clinical aspects and molecules and compounds concerned. Central Product Safety, Rusham Park, Whitehall Lane, Egham Suarrey. United Kingdon: Procter \& Gamble, 2011. 5 p.

NÓBREGA, A.M.; ALVES, E.N.; PRESGRAVE, R.F.; DELGADO, I.F. Avaliação da irritabilidade ocular induzida por ingredientes de cosméticos através do teste de Draize e dos Métodos HET-CAM e RBC. Universitas: Ciências da Saúde, v.6, n.2, p.103-120, 2008.

ORGANISATION FOR ECONOMIC CO-OPERATION AND DEVELOPMENT. OECD Guideline for the Testing of Chemicals $N^{\circ} 439$. In vitro skin irritation: reconstructed human epidermis test method. Paris: OECD, 2010. Available at: <http://www.oecd-ilibrary.org/environment/ oecd-guidelines-for-the-testing-of-chemicals-section-4health-effects_20745788>. Accessed on: 06 Nov. 2014.

ORGANISATION FOR ECONOMIC CO-OPERATION AND DEVELOPMENT. OECD Guideline for the testing of chemicals: in vitro skin corrosion: human skin model test. Paris: Guideline 431, 2004. 
PRICE, J.B.; ANDREWS, L.J. The in vitro assessment of eye irritancy using isolated eyes. Food Chem. Toxicol., v.23, n.2, p.313-315, 1985.

RAYMUNDO, M.M.; GOLDIM, J.R. Ética da pesquisa em modelos animais. Rev. Bioética, v.10, n.1, p.31-44, 2002.

RESOLUÇÃO DA DIRETORIA COLEGIADA. RDC. N.211. De 14 de julho de 2005. Diário Oficial da União, Brasília, DF, 18/07/2005, Seção 1, p.58.

RESOLUÇÃO DA DIRETORIA COLEGIADA - RDC 79, de 31 de agosto de 2000. Diário Oficial da União, Brasília, DF, 31 ago. 2000. Seção 1, p.34.

RESOLUÇÃO DA DIRETORIA COLEGIADA. RDC 196. Resolução $n^{\circ}$ 196/96, de 14 de janeiro de 1987. Diretrizes e Normas Regulamentadoras de Pesquisas Envolvendo Seres Humanos. Conselho Nacional de Saúde. Brasília, DF, 14 jan. 1987.

RESOLUÇÃO DA DIRETORIA COLEGIADA - RDC 343. Resolução $n^{\circ} 343$, de 13 de dezembro de 2005. Diário Oficial da República do Brasil. Brasília, DF, 13 dez. 2005.

SCOTT, L.; ESKES, C.; HOFFMANN, S.; ADRIAENS, E.; ALÉPÉE, N.; BUFO, M.; CLOTHIER, R.; FACCHINI, D.; FALLER, C.; GUEST, R.; HARBELL, J.; HARTUNG, T.; KAMP, H.; LE VARLET, B.; MELONI, M.; McNAMEE, P.; OSBORNE, R.; PAPE, W.; PFANNENBECKER, U.; PRINSEN, M.; SEAMAN, C.; SPIELMAN, H.; STOKES, W.; TROUBA, K.; VAN DEN BERGHE, C.; VAN GOETHEM, F.; VASSALLO, M.; VINARDELL, P.; ZUANG, V. A proposed eye irritation testing strategy to reduce and replace in vivo studies using Bottom-Up and Top-Down approaches. Toxicol. in Vitro, v.24, n.1, p.1-9, 2010.
TANI, N.; KINOSHITA, S.; OKAMOTO, Y.; KOTANI, M.; ITAGAKI, H.; MURAKAMI, N. Interlaboratory validation of in vitro eye irritation test for cosmetic ingredients. Evaluation of cytotoxicity test on SIRC cells. Toxicol. in Vitro, v.13, n.1, p.175-187, 1999.

UNITED NATIONS. UN. United Nations Globally Harmonized System of Classification and Labelling of Chemicals (GHS), ST/SG/AC.10/30, UN. New York and Geneva: 2009. Available at: <http://www.unece.org/trans/danger/publi/ ghs/ghs_welcome_e.html>.Accessed on: 06 Nov. 2014.

VAN GOETHEM, F. The in vitro "Bovine Cornea Opacitypermeability” eye irritation teste. Bélgica: John \& Johnson Pharmaceutical Research \& Development, 2011.

WILHELMUS, K.R. Therapeutic reviews: the draize eye test. Surv. Ophtalmol., v.45, n.6, p.493-515, 2001.

WOLFGAN, J.W.P.; PFNNENBECKER, U.; HOPPE, U. Validation of red bloos cell test system as in vitro assay for the rapid screening of irritation potential of surfactants. Mol. Toxicol., v.1, n.4, p.525-36, 1987.

ZUANG, V. The validation process of alternative methods in safety assessment of cometics: atual status and future. In vitro Methods Unit/ECVAM. Ispra: Institute for Health and Consumer Protection. 2011.

Received for publication on $19^{\text {th }}$ June 2013 Accepted for publication on $31^{\text {st }}$ Mach 2014 